\title{
Teaching the Effect of Variations in Types of Flour on Mechanical Characteristics of Chicken Skin Crackers through Experimental Demonstrations to Senior High School Students
}

\author{
Sri Anggraeni, Shafwa Faza Nadhira, Nissa Nur Azizah, Dwi Fitria Al Husaeni, Risti Ragadhita, Siti Nur \\ Hofifah, Asep Bayu Dani Nandiyanto*
}

Universitas Pendidikan Indonesia, J1. Dr. Setiabudhi No. 229 Bandung, Indonesia

anggraeni_said@upi.edu,shafwafaza@upi.edu,nissanrazizah@upi.edu,dwifitriaalhusaeni@upi.edu, ristiragadhita@student.upi.edu, sitinurhofifah@upi.edu,nandiyanto@upi.edu,

\begin{abstract}
This study aims to analyze video learning strategies on science learning outcomes and the effects of various types of cooking on chicken skin cracker mechanics for high school students. The research is conducted through experimental methods with the students by three stages including conducting pre-test, giving an instructional video, and conducting post-test. The making of chicken skin crackers is performed through washing, seasoning, drying, coating using different variations of flour (tapioca, wheat, maize, and sago flour), and frying the chicken skin. Testing the mechanical properties of chicken skin crackers is carried out using a hardness and puncture test. The research shows that the crunchiest texture is chicken skin crackers made from sago, corn, wheat, and tapioca flour respectively because chicken skin crackers that use sago flour have a more porous texture. Based on the results of the study, it can be concluded that the experimental demonstration is effective in improving students' learning outcomes regarding the effect of variations in flour type on the mechanical characteristics of chicken skin crackers, which is indicated by the posttest average score which is higher than the pretest score after the video is shown. Besides, this research also demonstrates the use of food scraps in new products to reduce waste.
\end{abstract}

Keywords: Chicken skin crackers. Experimental demonstration, Science education, Types of flour.

\section{Corresponding Author}

*Departemen Pendidikan Kimia, Universitas

Pendidikan Indonesia, J1. Dr. Setiabudi No. 229

Bandung, Indonesia

*nandiyanto@upi.edu

\section{Introduction}

Chicken skin is one of the livestock production commodities that can be utilized and it has nutritional value in the form of protein and fat. Chicken skin can be processed into snacks or can be used as a side dish in the form of chicken skin chips (Cakmak, Altinel, Kumcuoglu, Kisla, and Tavman, 2016). Chicken skin crackers are snacks made from chicken skin and flour. These crackers are popular in the Indonesian community because of their delicious taste and easily available ingredients. Skin crackers are generally fried with various types of flour, such as tapioca flour, wheat flour, sago flour, and rice flour (Oduor-Odote and Kazungu, 2008). Complementary ingredients such as powdered broth, salt, and pepper which are added in the manufacture of chicken skin crackers also contribute to the richness of the chicken skin crackers. Besides, various types of flour can produce a distinctly different crunchiness, texture, and flavor to people's tastes.

A study (Homkhiew, Ratanawilai, and Thongruang, 2015) shows that the type of flour has a significant effect on mechanical properties, oil absorption, serving size, and ash content, where the type of maize flour has a significant effect on texture (physical test) and crunchiness (organoleptic test). Besides, the effect of the type of maize flour has a significant effect on texture (physical test) and crunchiness (organoleptic test). The use of maize flour in crackers production has some disadvantages. The crackers are less attractive and taste a little gritty (Millar, Barry-Ryan, Burke, Hussey, McCarthy, and Gallagher, 2017). Various types of flour are also known to affect the physical effects of crackers because of the different nutritional content. Several studies on the effect of flour on various types of crackers have been carried out such as buffalo skin cracker (Hardoko and Utami, 2020), banana peel crackers (Zoair, Attia, Abou Garbia, and Youssef, 2016), White Snapper Fish Skin Rambak crackers (Hardoko and Utami, 2020) and squid crackers (Jumiati, Ratnasari, and Sudianto, 2019), however, there has been no research on the effect of variations in types of flour in 
making chicken skin crackers. Therefore, a study is conducted to determine the type of flour that is best used as a raw material for making chicken skin crackers based on the level of crispness and composition ratio.

The physical and mechanical characteristics of the crackers are influenced by the chemical composition of the main ingredients. In this study, we use four types of flour, namely wheat flour, tapioca, maize, and sago. All of the flour chemical compositions are shown in Table 1.

Table 1. Chemical composition of the flour

\begin{tabular}{|c|c|c|c|c|}
\hline Component & $\begin{array}{c}\text { Carbohydrate } \\
\text { (g) (Auliah, } \\
\text { 2012) }\end{array}$ & Protein (gram) & $\begin{array}{c}\text { Fat (g) } \\
\text { (Auliah, } \\
\text { 2012) }\end{array}$ & $\begin{array}{c}\text { Water (g) } \\
\text { (Auliah, } \\
\text { 2012) }\end{array}$ \\
\hline $\begin{array}{c}\text { Wheat } \\
\text { flour }\end{array}$ & 73 & $\begin{array}{c}9 \% \\
\text { (Tjokrokusomo, } \\
\text { Octaviani, } \\
\text { Sarangih, 2019 }\end{array}$ & 22,8 & 94 \\
\hline Tapioca & 12 & $\begin{array}{c}2 \% \text { (Alfani } \\
\text { Ishartani, } \\
\text { Anam, } \\
\text { Praseptiangga, } \\
\text { Manuhara, } \\
\text { 2019) }\end{array}$ & 3,5 & 0,2 \\
\hline Maize & 1,4 & $\begin{array}{c}8-12 \% \\
\text { (Bonea, 2020) }\end{array}$ & 1,0 & 0,2 \\
\hline Sago & $\begin{array}{c}19 \% \text { (Konuma, } \\
\text { Rolle, } \\
\text { Boromthanarat, } \\
\text { 2012) }\end{array}$ & 72,7 & 14 \\
\hline
\end{tabular}

This research is indeed appropriate for high school students in the science program because the material about nutrition in food has not been taught in detail. Therefore, the purpose of this study is to demonstrate the chemical composition and physical characteristics of food in high school students, in particular as regards the effect of variations in flour types on the properties of foods. This study also demonstrates mechanical chicken skin crackers with an experimental demonstration to students and analyses students learning outcomes through pretest, video presentation, and posttest. Research with demonstration experimental methods is expected to help students in understanding science subjects, specifically on the topic of learning chemical composition, physical characteristics, and mechanical properties of food.

\section{Method}

\subsection{Materials}

The main ingredients used in this study are fresh chicken skin (from a local market, Indonesia), salt (produced by PT Susanti Megah, Indonesia), garlic (from a local market, Indonesia), Royco powder broth (produced by Unilever, Indonesia), Sunco cooking oil (produced by PT Musim Mas Group, Indonesia), and Aquades water (produced by Sakura medical center).

\subsection{Chicken skin crackers production}

For this experiment, we made chicken skin crackers. First, the chicken skin was collected, scraped the excess fat off and the remaining meat then washed with running water to clean the remaining blood, feathers, and dirt that still attached. The skin was stretched out flat and sprinkle with a pinch of salt and then cut into a reasonable shape. The chicken skin was then mixed with salt, broth powder, and mashed garlic. After that, we dried the skin under the sun and when it was sufficiently dry, it was divided into four containers and coated them with four different flours, namely wheat flour, tapioca flour, cornstarch, and sago flour. Lastly, we fried the chicken skin in hot oil. After the skin turned golden brown and crisp, we placed the skins on kitchen paper to make it cool.

\subsection{Mechanical characteristics test on chicken skin crackers}

The mechanical test was conducted to determine the mechanical characteristics of chicken skin crackers. We performed two tests namely the hardness test and the puncture test. The puncture test was carried out using a Screw Stand Test Instrument (Mode I ALX-J, China) and the cracker hardness and crispness tests were conducted by using a press test using the Shore Durometer instrument (Shore A Hardness, In size, China). The puncture test was carried out to measure the force by inserting a needle or probe into several points on the chicken skin crackers until there were hollows and the texture profile is obtained. The compressive test was carried out by applying a compressive force to the chicken skin crackers, and the result was a curve showing the texture profile of the chicken skin crackers. Hardness is expressed as the maximum force (peak value) in Newtons (N).

\subsection{Teaching methods}

The teaching method was an experimental demonstration. The subjects in this study were 18 high school students taking a science program from various regions in Indonesia. Subjects consisted of $16.7 \%$ male students and $83.3 \%$ female students. There were several stages that we conducted including providing a pre-test to assess students' knowledge. After that, we presented a learning video with a brief explanation of the topic. Furthermore, the last stage was given posttest questions to measure students' learning outcomes after being given a learning video. There are 15 with true or false questions for the pretest and posttest. To simplify students' answers, all the answers are marked as 1 for the correct answer and 0 for an incorrect answer. Before conducting the lesson, information on students' scores on Mathematics, Chemistry, Physics, and Biology was collected to support the research instrument.

\subsection{Biodegradation test of chicken skin crackers}

Furthermore, a biodegradation test was conducted to determine the resistance of chicken skin cracker products. In the biodegradation test, samples of chicken skin crackers from each different flour with a length and width of $2-3 \mathrm{~cm}$ and a height of $0.2 \mathrm{~cm}$ were weighed and immersed in a small bottle containing $60 \mathrm{ml}$ of distilled water. The bottle 
was tightly closed and placed in a room without direct sunlight for $1,2,4,6,8$, and 10 days. After reaching the predetermined time, the samples were removed and ovendried at a temperature of $175^{\circ} \mathrm{C}$ for $15 \mathrm{~min}$. Samples were weighed again to determine the reduction in mass that occurs during the biodegradation process in bottles. The data obtained from the biodegradation test are in the form of mass reduction data.

\section{Results and Discussion}

\subsection{Mechanical characteristics test of chicken skin crackers}

The chicken skin crackers coated using wheat, sago, maize, and tapioca flour are shown in Figure 1. The type of flour used affects the color of the chicken skin crackers (Aziah and Komatchi, 2009). Chicken skin crackers made from wheat and maize flour have a darker brown color and a smoother texture, while the skin crackers made from tapioca and sago flour have a lighter brown color, coarser, and more bubbly texture. The bubbles are visible on the surface of the fried chicken skin crackers. The chicken crackers made from sago flour look bigger than chicken skin made from tapioca flour (Leonel, Freitas, and Mischan, 2009).

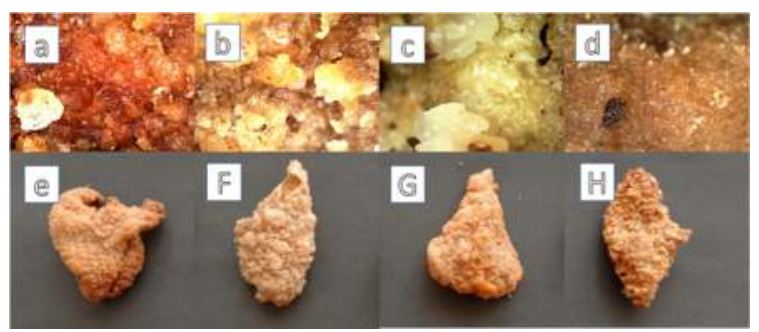

Fig. 1 (a-d) microscope results of chicken skin crackers with variations of wheat flour, sago, maize, and tapioca. (e-h) results of chicken skin crackers with variations of wheat flour, sago, maize, and tapioca.

Figure 2 shows the results of the mechanical test on the production of chicken skin crackers with various types of flour using the hardness test. The higher the force applied to the hardness test, the higher the number indicates a texture that is harder and harder to destroy (low crispness) (Philipp, Buckow, Silcock, and Oey, 2017). Whereas, Table 2 displays the results of the prick test. The higher the value produced, the crunchier the skin cracker texture (Zdunek, Cybulska, Konopacka, and Rutkowski, 2010). The two methods used show that the chicken skin crackers with the hardest texture are chicken skin crackers made from tapioca, wheat, corn, and sago flour.

Chicken skin crackers made from sago flour have the crunchiest texture because the large flour granules can bind more water (Hansdah, Prabhakar, Srivastav, and Mishra, 2015). Furthermore, water particles in sago flour evaporate when heated, causing the surface structure of the skin crackers brittle and the texture crispy.

Chicken skin crackers made from maize flour also have a fairly crunchy texture because they have a high moisture content. Water particles in maize flour evaporate when heated and create crunchy textures (Fall, Bertrand, Ovarlez, and Bonn, 2012). Maize flour has a high protein content, causing the texture of chicken more porous than the chicken skin crackers made from sago flour.

Besides, chicken skin crackers made from wheat flour have porous textures than crackers made from sago and maize flour because wheat flour contains high levels of protein and water. The composition of protein and water forms gluten and makes food made from wheat flour have porous and hard textures ( $\mathrm{Li}$, Hou, Chen, Chung, and Gehring, 2014).

Chicken skin crackers made from tapioca flour have the thickest and hardest texture. Tapioca flour forms chewy and porous textures when exposed to water (Liu, Sun, Zhang, Huang, Hu, and Zhao, 2019). High temperature and frying time are known to increase the moisture content in tapioca flour (Saeleaw, 2011). This makes the tapioca flour crackers solid and hard.

In food production, when flour is heated, the moisture content decreases, and various changes occur due to its composition. According to (Wandsnider, 1997), when heated, carbohydrates undergo gelatinization and dextrinization, which produce white to yellowish colors. The gelatinization that is observed in the micromolecules will break down carbohydrates over time. The particles in fat undergo hydrolysis and produce a distinctive smell. Also, protein is denatured, giving the food a soft texture.

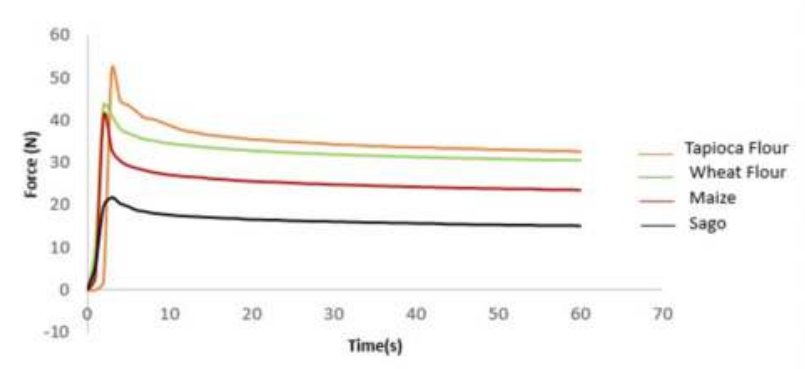

Fig. 2 Graph of compressive test results

Table 2. Puncture test results

\begin{tabular}{|c|c|c|c|c|}
\hline \multirow{2}{*}{ No } & \multicolumn{5}{|c|}{ Flour variant } \\
\cline { 2 - 5 } & Tapioca & Wheat & Maize & Sago \\
\hline 1 & 43 & 50 & 63 & 60 \\
\hline 2 & 31 & 55 & 64 & 69 \\
\hline 3 & 33 & 64 & 67 & 61 \\
\hline 4 & 33 & 61 & 63 & 67 \\
\hline 5 & 30 & 53 & 63 & 59 \\
\hline 6 & 40 & 53 & 53 & 63 \\
\hline Average & $\mathbf{3 5}$ & $\mathbf{5 6}$ & $\mathbf{6 2 , 1 6}$ & $\mathbf{6 3 , 1 6}$ \\
\hline
\end{tabular}

\subsection{Biodegradation test}

Table 3 displays the results of biodegradation of the flour variation effects in the making of chicken skin crackers. This analysis is important to ensure that the food is good for 
consumption (Nandiyanto, Fiandini, Ragadhita, Sukmafitri, Salam, and Triawan, 2020). The use of maize flour makes the degradation process faster and the average mass decreases by 76.43 because maize is the most susceptible to moisture compared to other flours (Imam, Gordon, Mohamed, Harry-O'kuru, Chiou, Glenn, and Orts, 2006). Most maize flour dissolves in water and also decomposes most of its mass, unlike chicken skin crackers which are made from wheat flour which is denser so it can retain its mass (Sreekumar, Leblanc, and Saiter, 2013).

Table 3. Biodegradation results

\begin{tabular}{|c|c|c|c|c|c|}
\hline $\begin{array}{l}\text { Type of } \\
\text { flour }\end{array}$ & Day & Decay & $\begin{array}{l}\text { The decay } \\
\text { dimension }\end{array}$ & $\begin{array}{c}\text { Weight } \\
\text { Loss }\end{array}$ & Average \\
\hline \multirow{7}{*}{ Wheat } & 1 & 0.07 & 0.003825137 & 6 & \multirow{7}{*}{59.86} \\
\hline & 2 & 0.01 & 0.000813008 & 1 & \\
\hline & 4 & 1.25 & 0.057710065 & 69 & \\
\hline & 6 & 1.06 & 0.045650301 & 91 & \\
\hline & 8 & 1.15 & 0.05450237 & 91 & \\
\hline & 10 & 1.72 & 0.069076305 & 87 & \\
\hline & 14 & 1.71 & 0.064723694 & 74 & \\
\hline \multirow{7}{*}{ Tapioca } & 1 & 0.14 & 0.010279001 & 47 & \multirow{7}{*}{66.43} \\
\hline & 2 & 0.57 & 0.031147541 & 39 & \\
\hline & 4 & 0.89 & 0.039661319 & 71 & \\
\hline & 6 & 0.81 & 0.039435248 & 41 & \\
\hline & 8 & 1.34 & 0.058464223 & 92 & \\
\hline & 10 & 1.03 & 0.039403213 & 84 & \\
\hline & 14 & 1.28 & 0.047940075 & 91 & \\
\hline \multirow{7}{*}{ Maize } & 1 & 0.28 & 0.016184971 & 93 & \multirow{7}{*}{76.43} \\
\hline & 2 & 1.2 & 0.06006006 & 65 & \\
\hline & 4 & 0.89 & 0.054534314 & 70 & \\
\hline & 6 & 0.58 & 0.040333797 & 57 & \\
\hline & 8 & 1.43 & 0.066203704 & 87 & \\
\hline & 10 & 2.05 & 0.112021858 & 76 & \\
\hline & 14 & 1.58 & 0.06167057 & 87 & \\
\hline \multirow{7}{*}{ Sago } & 1 & 0.22 & 0.016717325 & 73 & \multirow{7}{*}{76.14} \\
\hline & 2 & 0.29 & 0.018709677 & 29 & \\
\hline & 4 & 1.69 & 0.048563218 & 93 & \\
\hline & 6 & 1.07 & 0.049537037 & 79 & \\
\hline & 8 & 1.13 & 0.049604917 & 77 & \\
\hline & 10 & 2.04 & 0.067594433 & 89 & \\
\hline & 14 & 1.3 & 0.036252091 & 93 & \\
\hline
\end{tabular}

\subsection{Student demography}

Table 4 illustrates the average value of science subjects (Mathematics, Physics, Biology, Chemistry). The table shows that the student's average score is 8 . This shows that the students' mastery of science is good (Kim, Kim, Yuan, Hill, Doshi, and Thai, 2015).

Table 4. Average grades of subjects

\begin{tabular}{|c|c|}
\hline Subjects & Average value \\
\hline Mathematics & 7.93 \\
\hline Physics & 7.93 \\
\hline Biology & 7.87 \\
\hline Chemistry & 8.27 \\
\hline
\end{tabular}

\subsection{Learning outcome data analysis}

The use of video as a learning medium has a positive impact on students' perceptions of increasing their enthusiasm for learning (Bourgonjon, Valcke, Soetaert, and Schellens, 2010). After completing the pretest, students are encouraged to watch the learning video of the points mentioned in the pretest. Students will become more aware and interested in the impact of nutrient composition on the characteristics of food consumed in everyday activities. Thus, the students' posttest scores improve after watching the video.

Table 5 presents the acquisition of pretest and posttest scores of 18 high school students in total. From the table, it can be seen that the level of students' understanding of the material about the variety of chicken skin crackers increase after the experimental method is conducted. As seen in the pre-test mean score of $56.51 \%$ and the post-test mean score increased to $75.17 \%$. In addition, based on the results of the pretest which compare to the acquisition of students' posttest scores, it shows that the T count (2.1448) is greater than the $\mathrm{T}$ table (-4.3531) which states that the students' post-test scores increase significantly (Alekseyenko, 2016).

This increase in score occurs because the experimental method and video help students understand the content. The learning video that is presented attracts students' attention because the video provides new information about the topics that students encounter in everyday life (Wang and Antonenko, 2017). Based on the progress score, it can be concluded that the experimental demonstration method is effective for teaching and learning activities, this is following a study which states that experimental demonstration methods, in particular, the use of video learning media are effective in improving student learning (Suprianto, Ahmadi, and Suminar, 2019).

However, the use of online learning videos has not been able to use real methods to illustrate learning. Although the video method is less effective than the direct method (Visvawom and Joby, 2017) yet the two methods can be combined to provide optimal learning outcomes.

Table 5. The results of the students' pre-test and post-test

\begin{tabular}{|c|c|c|c|}
\hline No & Question & $\begin{array}{c}\text { Pretest } \\
\text { (\%) }\end{array}$ & $\begin{array}{c}\text { Posttest } \\
\text { (\%) }\end{array}$ \\
\hline 1 & $\begin{array}{c}\text { Chicken skin crackers are made from } \\
\text { different types of flour, namely maize, } \\
\text { tapioca, sago, and wheat flour. The variation } \\
\text { of flour will create products with different } \\
\text { levels of hardness }\end{array}$ & 85.70 & 100 \\
\hline 2 & $\begin{array}{c}\text { The protein content in food affects the food } \\
\text { texture }\end{array}$ & 47.60 & 94.40 \\
\hline
\end{tabular}




\begin{tabular}{|c|c|c|c|}
\hline No & Question & $\begin{array}{c}\text { Pretest } \\
(\%)\end{array}$ & $\begin{array}{c}\text { Posttest } \\
(\%)\end{array}$ \\
\hline 3 & $\begin{array}{c}\text { The savory taste of food is determined by } \\
\text { protein }\end{array}$ & 47.60 & 94.40 \\
\hline 4 & Protein content can affect the food texture & 42.90 & 83.30 \\
\hline 5 & $\begin{array}{l}\text { The ingredients in food will spoil when } \\
\text { heated at a temperature of more than } 100^{\circ} \mathrm{C}\end{array}$ & 85.70 & 94.40 \\
\hline 6 & $\begin{array}{c}\text { In the biodegradation test, food samples are } \\
\text { immersed in small bottles then closed, when } \\
\text { opens after a few days there will be gas and } \\
\text { bad odor. This event is caused by aerobic } \\
\text { fermentation. }\end{array}$ & 14.30 & 50.00 \\
\hline 7 & $\begin{array}{l}\text { Tapioca flour has a very low protein content. } \\
\text { This makes the chicken skin crackers made } \\
\text { from tapioca flour have the softest texture }\end{array}$ & 42.90 & 55.60 \\
\hline 8 & $\begin{array}{l}\text { Maize flour, which easily absorbs oil, makes } \\
\text { the skin cracker texture crunchy }\end{array}$ & 52.40 & 50.00 \\
\hline 9 & $\begin{array}{l}\text { The softer the chicken skin crackers texture, } \\
\text { the higher the protein content is. }\end{array}$ & 47.60 & 66.70 \\
\hline 10 & $\begin{array}{l}\text { The high-fat content in maize flour gives the } \\
\text { skin crackers a savory taste }\end{array}$ & 66.70 & 72.20 \\
\hline 11 & $\begin{array}{l}\text { Sago flour that absorbs water easily makes } \\
\text { the skin cracker texture crunchy }\end{array}$ & 47.60 & 61.10 \\
\hline 12 & $\begin{array}{l}\text { The high protein content in wheat flour } \\
\text { makes the chicken skin cracker texture crispy }\end{array}$ & 52.40 & 55.60 \\
\hline 13 & $\begin{array}{l}\text { To determine the physical characteristics of } \\
\text { chicken skin crackers, the compressive test is } \\
\text { a mechanical test which results in a graph }\end{array}$ & 85.70 & 83.30 \\
\hline 14 & $\begin{array}{l}\text { Sago flour contains low levels of fat so it can } \\
\text { give a savory taste to chicken skin crackers }\end{array}$ & 66.70 & 88.20 \\
\hline 15 & $\begin{array}{c}\text { Puncture test is a mechanical test method that } \\
\text { can measure the hardness level of chicken } \\
\text { skin crackers }\end{array}$ & 61.90 & 77.80 \\
\hline \multicolumn{2}{|r|}{ Average } & $\begin{array}{l}56.51 \\
\end{array}$ & 75.17 \\
\hline
\end{tabular}

\section{Conclusions}

The mechanical test results show that the chicken skin crackers made from sago flour are the crunchiest crackers. In the biodegradation test, it is found that maize flour is the easiest to decompose, which means that it has a short shelf life. The research also shows that based on the posttest average score which is higher than the pretest score, it can be concluded that the experimental demonstration method in learning is effective.

\section{Acknowledgements}

This study acknowledged RISTEK BRIN for Grant-inaid Penelitian Terapan (PT) and Penelitian Terapan Unggulan Perguruan Tinggi (PTUPT).

\section{References}

Alekseyenko, A. V. (2016). Multivariate Welch t-test on distances. Bioinformatics, 32(23), 3552-3558.

Aziah, N. A. A., and Komathi, C. A. (2009). Acceptability attributes of crackers made from different types of composite flour. International Food Research Journal, 16(4), 479-482.

Bourgonjon, J., Valcke, M., Soetaert, R., and Schellens, T. (2010). Students' perceptions about the use of video games in the classroom. Computers \& Education, 54(4), 11451156 .
Cakmak, H., Altinel, B., Kumcuoglu, S., Kisla, D., and Tavman, S. (2016). Production of crispy bread snacks containing chicken meat and chicken meat powder. Anais da Academia Brasileira de Ciências, 88(4), 2387-2399.

Fall, A., Bertrand, F., Ovarlez, G., and Bonn, D. (2012). Shear thickening of cornstarch suspensions. Journal of rheology, 56(3), 575-591.

Hansdah, R., Prabhakar, P. K., Srivastav, P. P., and Mishra, H. N. (2015). Physico-chemical characterization of lesser known Palo (Curcuma leucorrhiza) starch. International Food Research Journal, 22(4), 1368-1373.

Hardoko, H., and Utami, S. (2020). Chemical-Physical properties characterization of white snapper fish skin rambak crackers based on boiling and drying duration. Jurnal Ilmiah Perikanan dan Kelautan, 12(1), 122-130.

Homkhiew, C., Ratanawilai, T., and Thongruang, W. (2015). Composites from recycled polypropylene and rubberwood flour: effects of composition on mechanical properties. Journal of Thermoplastic Composite Materials, 28(2), 179194.

Imam, S. H., Gordon, S. H., Mohamed, A., Harry-O'kuru, R., Chiou, B. S., Glenn, G. M., and Orts, W. J. (2006). Enzyme catalysis of insoluble cornstarch granules: Impact on surface morphology, properties and biodegradability. Polymer degradation and stability, 91(12), 2894-2900.

Jumiati, J., Ratnasari, D., and Sudianto, A. (2019). Effect of using turmeric extract (curcuma domestica) on the quality of squid crackers (Loligo sp.). Jurnal Ilmiah Perikanan dan Kelautan, 11(1), 55-61.

Kim, C., Kim, D., Yuan, J., Hill, R. B., Doshi, P., and Thai, C. N. (2015). Robotics to promote elementary education preservice teachers' STEM engagement, learning, and teaching. Computers \& Education, 91(2015), 14-31.

Leonel, M., Freitas, T. S. D., and Mischan, M. M. (2009). Physical characteristics of extruded cassava starch. Scientia Agricola, 66(4), 486-493.

Li, J., Hou, G. G., Chen, Z., Chung, A. L., and Gehring, K. (2014). Studying the effects of whole-wheat flour on the rheological properties and the quality attributes of wholewheat saltine cracker using SRC, alveograph, rheometer, and NMR technique. LWT-Food Science and Technology, 55(1), 43-50.

Liu, R., Sun, W., Zhang, Y., Huang, Z., Hu, H., and Zhao, M. (2019). Preparation of starch dough using damaged cassava starch induced by mechanical activation to develop staple foods: Application in crackers. Food Chemistry, 271(2019), 284-290.

Millar, K. A., Barry-Ryan, C., Burke, R., Hussey, K., McCarthy, S., and Gallagher, E. (2017). Effect of pulse flours on the physiochemical characteristics and sensory acceptance of baked crackers. International Journal of Food Science \& Technology, 52(5), 1155-1163. 
Nandiyanto, A. B. D., Fiandini, M., Ragadhita, R., Sukmafitri, A., Salam, H., and Triawan, F. (2020). Mechanical and biodegradation properties of cornstarchbased bioplastic material. Materials Physics and Mechanics, 44, 380-391.

Oduor-Odote, P. M., and Kazungu, J. M. (2008). The body composition of low value fish and their preparation into a higher value snack food. Western Indian Ocean Journal of Marine Science, 7(1), 111-117.

Philipp, C., Buckow, R., Silcock, P., and Oey, I. (2017). Instrumental and sensory properties of pea protein-fortified extruded rice snacks. Food Research International, 102(2017), 658-665.

Saeleaw, M., and Schleining, G. (2010). Effect of blending cassava starch, rice, waxy rice and wheat flour on physicochemical properties of flour mixtures and mechanical and sound emission properties of cassava crackers. Journal of Food Engineering, 100(1), 12-24.

Suprianto, A., Ahmadi, F., and Suminar, T. (2019). The development of mathematics mobile learning media to improve students' autonomous and learning outcomes. Journal of Primary Education, 8(1), 84-91.

Sreekumar, P. A., Leblanc, N., and Saiter, J. M. (2013). Effect of glycerol on the properties of $100 \%$ biodegradable thermoplastic based on wheat flour. Journal of Polymers and the Environment, 21(2), 388-394.

ViSwASom, A. A., and Jobby, A. (2017). Effectiveness of video demonstration over conventional methods in teaching osteology in anatomy. Journal of Clinical and Diagnostic Research: JCDR, 11(2), 9-11.

Wandsnider, L. (1997). The roasted and the boiled: food composition and heat treatment with special emphasis on pithearth cooking. Journal of anthropological archaeology, 16(1), 1-48.

Wang, J., and Antonenko, P. D. (2017). Instructor presence in instructional video: Effects on visual attention, recall, and perceived learning. Computers in Human Behavior, 71(2017), 79-89.

Zdunek, A., Cybulska, J., Konopacka, D., and Rutkowski, K. (2010). New contact acoustic emission detector for texture evaluation of apples. Journal of Food Engineering, 99(1), 83-91.

Zoair, A. S. A., Attia, R. S., Abou Garbia, H. A., and Youssef, M. M. (2016). Utilization of orange, banana and potato peels in formulating functional cupcakes and crackers. Alexandria Journal of Food Science and Technology, 13(2), 11-18. 